\title{
Cara Preservasi Fitoplasma dari Jaringan Kacang Tanah Bergejala Sapu untuk Deteksi DNA dengan Teknik PCR
}

\author{
Phytoplasma Preservation Methods of Symptomatic \\ Peanut Witches' broom for DNA Detection Using PCR Technique
}

\author{
Siska Irhamnawati Pulogu, Kikin Hamzah Mutaqin*, Giyanto \\ Institut Pertanian Bogor, Bogor 16680
}

\begin{abstract}
ABSTRAK
Penyakit sapu (witches' broom) oleh fitoplasma pada kacang tanah adalah penyakit umum di Indonesia. Fitoplasma dapat dideteksi dengan teknik polymerase chain reaction (PCR). Salah satu faktor penentu keberhasilan deteksi fitoplasma ialah penyediaan DNA dari contoh segar. Penelitian bertujuan mengevaluasi beberapa cara preservasi sampel tanaman terinfeksi fitoplasma. Aspek yang dievaluasi meliputi waktu $\left(1,2,3\right.$, dan 4 minggu), suhu $\left(-20^{\circ} \mathrm{C}, 4^{\circ} \mathrm{C}\right.$, dan $\left.25^{\circ} \mathrm{C}\right)$, dan medium preservasi (bufer PGB $1 \mathrm{X}, \mathrm{NaCl} 3 \mathrm{M}$, bufer CTAB, Alkohol 70\%, tanpa medium, dan kertas FTA) untuk mempertahankan jaringan tanaman terinfeksi supaya tetap segar. Cara preservasi yang baik akan mengoptimalkan deteksi DNA fitoplasma dengan teknik PCR standar yang dilanjutkan dengan teknik nested-PCR. Penyimpanan pada suhu $-20{ }^{\circ} \mathrm{C}, 4{ }^{\circ} \mathrm{C}$ dan $25{ }^{\circ} \mathrm{C}$ dalam medium CTAB dapat mempertahankan jaringan tetap segar selama 4 minggu dengan kualitas dan kuantitas DNA yang cukup untuk deteksi dengan teknik PCR. Teknik PCR standar dengan pasangan primer P1/P7 menunjukkan bahwa tidak semua DNA fitoplasma dari hasil preservasi contoh terdeteksi positif. Namun, PCR standar yang dilanjutkan dengan nestedPCR menggunakan primer fU5/rU5 mampu meningkatkan pendeteksian fitoplasma yang berasal dari preservasi contoh pada berbagai medium selama 4 minggu dengan memberikan hasil positif dari contoh yang terdeteksi negatif pada teknik PCR standar.
\end{abstract}

Kata kunci: nested-PCR, PCR standar, penyimpanan, sapu kacang tanah

\begin{abstract}
Witches' broom of peanut caused by phytoplasma is a common disease found in Indonesia. Phytoplasma is able to be detected using polymerase chain reaction (PCR) technique. One of important factor which determine the successful of phytoplasma amplification is the DNA availability from fresh tissues. The research was aimed to evaluate some preservation methods of phytoplasma from infected plant samples. The aspects to be evaluated consisted of time $(1,2,3$, and 4 weeks), temperature (-20 ${ }^{\circ} \mathrm{C}, 4{ }^{\circ} \mathrm{C}$, and $25^{\circ} \mathrm{C}$ ), and preservation medium (1X PGB buffer, $3 \mathrm{M} \mathrm{NaCl}, \mathrm{CTAB}$ buffer, $70 \%$ ethanol, non medium, and FTA-card) for storing the fresh phytoplasma infected samples. Good preservation method will optimize the phytoplasma DNA amplification using PCR standard technique followed by nested-PCR. The results showed that preservation of samples at $-20^{\circ} \mathrm{C}, 4{ }^{\circ} \mathrm{C}$, and $25^{\circ} \mathrm{C}$ in CTAB buffer was able to maintain the tissue freshness for 4 weeks and was able to provide the DNA of either quality or quantity sufficiently for PCR detection. PCR standard using a primer pair P1/P7 showed that not all of the preserved DNA of phytoplasma were amplified positively. However, standard PCR followed by nested-PCR using primer pair fU5/rU3 was able to increase the DNA detectability. Preserved samples
\end{abstract}

*Alamat penulis korespondensi: Departemen Proteksi Tanaman, Fakultas Pertanian, Institut Pertanian Bogor, Jalan Kamper, Kampus IPB, Dramaga, Bogor 16680

Tel: 0251-7533525, Faks : 0251-8629364, Surel: kmutaqin@gmail.com 
derived from various medium and stored for 4 weeks gave positive results. This results were in contrary with previous same samples which were detected negatively by standard PCR technique.

Keywords: nested-PCR, preservation, peanut witches' broom, standard PCR

\section{PENDAHULUAN}

Di Indonesia fitoplasma telah menginfeksi beberapa tanaman penting seperti kacang tanah yang dapat menurunkan bobot polong sebesar 41-100\% (Nugroho et al. 2000). Selain itu, fitoplasma terdeteksi menyebabkan penyakit daun putih rumput bermuda, penyakit kuning bambu, penyakit daun kecil ubi jalar, dan penyakit sapu/proliferasi mosaik kaktus (Mutaqin et al. 2003).

Polymerase Chain Reaction (PCR) ialah teknik molekuler yang umum digunakan dalam deteksi dan identifikasi fitoplasma. Penyediaan contoh tanaman yang tetap segar sangat penting untuk isolasi DNA total. Faktor jarak jauh atau waktu yang lama dalam pengiriman contoh segar menjadi kendala dalam isolasi DNA karena deteriorasi jaringan dapat terjadi secara cepat dan munculnya senyawa inhibitor yang dapat memengaruhi kualitas dan kuantitas DNA dalam syarat teknik PCR (Nejat dan Vadamalai 2013). Titer fitoplasma dalam jaringan sangat rendah sehingga DNA yang diisolasi seringkali belum cukup dalam PCR standar untuk menghasilkan amplikon yang terlihat jelas. Oleh karena itu, modifikasi PCR untuk meningkatkan kemampuan deteksinya dengan PCR bersarang (nested-PCR) menggunakan pasangan primer untuk reamplifikasi DNA sasaran secara internal dalam wilayah sasaran PCR standar diperlukan (Gundersen dan Lee 1996). Penelitian bertujuan mengevaluasi cara preservasi jaringan tanaman bergejala sapu sehingga tetap diperoleh DNA yang layak dalam deteksi fitoplasma dengan PCR standar yang dilanjutkan dengan nested-PCR.

\section{BAHAN DAN METODE}

\section{Penyediaan dan Preservasi Tanaman Sakit}

Tanaman kacang tanah bergejala penyakit sapu diperoleh di Desa Cikarawang, Kecamatan Dramaga, Kabupaten Bogor. Tanaman tersebut diuji dengan PCR untuk memastikan terinfeksi oleh fitoplasma. Sebanyak $1 \mathrm{~g}$ contoh tanaman sakit berupa potongan batang muda, tangkai, dan tulang daun tanpa nekrosis disimpan dalam botol. Preservasi dilakukan dalam tiga aspek, yaitu lama penyimpanan $(1,2,3,4$ minggu), suhu penyimpanan $(-20,4$, dan 25 ${ }^{\circ} \mathrm{C}$ ), dan medium penyimpanan (bufer PGB1X [47.4 mM K $\mathrm{HPO}_{4} \cdot 3 \mathrm{H}_{2} \mathrm{O} ; 15 \mathrm{mM} \mathrm{KH} \mathrm{KO}_{4}$; Sukrosa 5\%; Polyvinylpyrrolidone-10 1\%], $\mathrm{NaCl} 3 \mathrm{M}$, bufer CTAB [CTAB 2\%; $1.4 \mathrm{M}$ $\mathrm{NaCl} ; 100 \mathrm{mM}$ Tris; $20 \mathrm{mM}$ EDTA; Polyvinylpyrrolidone-40 1\%], Alkohol 70\%, tanpa medium, dan kertas Flinders Technology Associates (FTA) sebagai pembanding. Preservasi dengan FTA-card (Whatman) dilakukan melalui blotting jaringan contoh sebanyak 0.1 g pada permukaan FTA-card, diinkubasi selama 5 menit pada suhu ruang dan selanjutnya disimpan pada suhu $-20^{\circ} \mathrm{C}$, $4{ }^{\circ} \mathrm{C}$, dan $25^{\circ} \mathrm{C}$.

\section{Isolasi DNA dari Jaringan Tanaman Sakit dan Pengukuran DNA}

Isolasi DNA secara total dari jaringan tanaman sakit dilakukan dengan metode Dellaporta et al. (1983). DNA total hasil ekstraksi maupun preservasi pada FTA-card diukur pada absorbansi 260/280 menggunakan spektrofotometer Nanodrop 2000 (Thermo Scientific) di IPB Culture Collection, Departemen Biologi.

\section{Amplifikasi DNA dengan PCR dan Nested- PCR}

Deteksi fitoplasma dengan PCR standar menggunakan pasangan primer P1/P7. Amplikon DNA hasil PCR standar (pengenceran 1:29) selanjutnya digunakan sebagai DNA templat dalam nested-PCR menggunakan pasangan primer fU5 (5'-CGG CAA TGG AGG AAA CT-3')/rU3 (5'-TTC AGC TAC TCT TTG TAA CA-3') (Lorenz et al. 1995). Reaksi PCR pada volume total 
$25 \mu \mathrm{L}$ terdiri atas DreamTaq Green PCR master mix 2X (Thermo Scientific) $12.5 \mu \mathrm{L}$, primer forward dan reverse $1 \mu \mathrm{L}(5 \mathrm{pmol}), \mathrm{ddH}_{2} \mathrm{O}$ $9.5 \mu \mathrm{L}$, dan DNA templat $1 \mu \mathrm{L}\left(1-2000 \mathrm{ng} \mu \mathrm{L}^{-1}\right)$. Aplikasi DNA dengan teknik PCR menggunakan mesin GeneAmp PCR System 9700 dengan kondisi denaturasi awal $92{ }^{\circ} \mathrm{C}$, 1 menit; denaturasi $94{ }^{\circ} \mathrm{C}, 1$ menit; aneling $55{ }^{\circ} \mathrm{C}$, 1 menit; ekstensi $72{ }^{\circ} \mathrm{C}, 1.5$ menit; ekstensi akhir $72{ }^{\circ} \mathrm{C}, 10$ menit. PCR dilakukan sebanyak 35 siklus. Nested-PCR menggunakan primer fU5/rU5 dan kondisinya hanya berbeda pada suhu aneling primer, yakni $57^{\circ} \mathrm{C}$ (Duduk et al. 2013). DNA hasil amplifikasi PCR dielektroforesis menggunakan gel agarosa $1 \%$ yang mengandung $\mathrm{EtBr}$ pada tegangan 75 Volt DC selama 30 menit. Hasil elektroforesis divisualisasi pada transilluminator UV untuk mengamati dan mendokumentasi pita DNA.

\section{HASIL}

\section{Deteksi Awal Penyakit Sapu pada Tanaman Kacang Tanah}

Tanaman kacang tanah yang terinfeksi fitoplasma umumnya akan menunjukkan gejala setelah berumur di atas 45 hari berupa daun kecil pada batang utama dan cabang. Pada batang utama terjadi pembentukan tunas samping yang terdiri atas daun kecil yang sangat banyak. Tanaman yang menunjukkan gejala tersebut selanjutnya dideteksi dengan teknik PCR standar. Hasil amplifikasi DNA dengan teknik PCR standar menunjukkan tanaman positif terinfeksi fitoplasma dengan terbentuknya pita DNA berukuran $\pm 1800 \mathrm{pb}$ (Gambar 1).

\section{Tanaman Kacang Tanah Terinfeksi Fitoplasma pada Berbagai Kondisi Preservasi}

Preservasi contoh tanaman terinfeksi pada suhu $-20{ }^{\circ} \mathrm{C}$ dalam berbagai medium selama 4 minggu secara keseluruhan tidak mengalami perubahan warna. Pada suhu $4{ }^{\circ} \mathrm{C}$ tanaman mengalami perubahan warna untuk beberapa contoh seperti perubahan warna dari warna hijau muda menjadi hijau kecokelatan, cokelat muda, dan cokelat tua pada medium $\mathrm{NaCl}$, alkohol, dan tanpa medium. Preservasi tanaman contoh pada suhu ruang $\left(25^{\circ} \mathrm{C}\right)$ dalam berbagai medium menunjukkan sebagian besar contoh mengalami perubahan warna hingga mengalami kerusakan/deteriorasi, kecuali pada medium CTAB. Contoh yang disimpan dalam medium CTAB selama 4 minggu tidak mengalami perubahan bentuk dan warna. Adapun preservasi DNA tanaman contoh dalam kertas FTA pada semua suhu mengalami kerusakan sejak minggu ke-1 (Tabel 1).

Konsentrasi dan kemurnian DNA total dari hasil preservasi contoh tanaman pada berbagai kondisi menunjukkan nilai yang beragam. Konsentrasi DNA berkisar 3-1303 ng $\mu \mathrm{L}^{-1}$

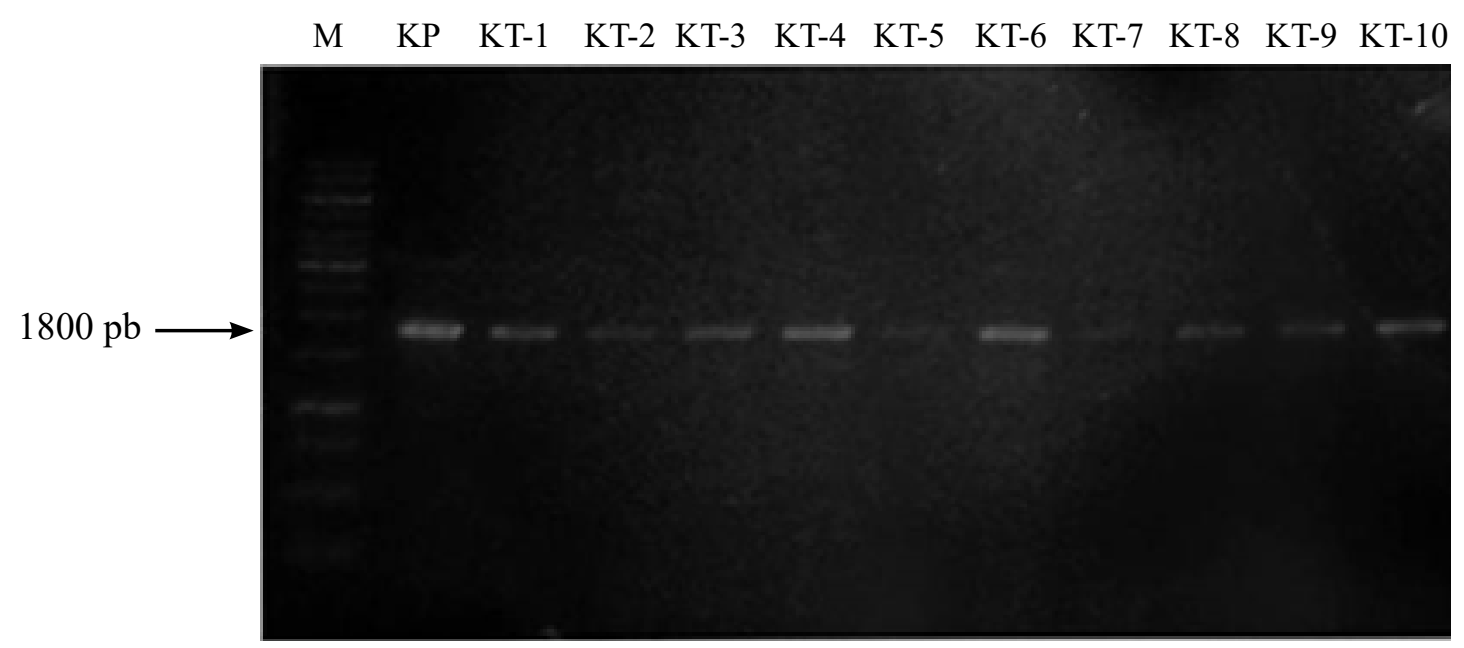

Gambar 2 Visualisasi fragmen DNA fitoplasma menggunakan primer P1/P7 hasil deteksi awal penyakit sapu tanaman kacang tanah. M, Penanda $1 \mathrm{~Kb}$; KP, kontrol positif; KT-1 s/d KT-10, tanaman kacang tanah terinfeksi fitoplasma. 
Tabel 1 Tingkat deteriorasi contoh terinfeksi fitoplasma pada berbagai perlakuan preservasi

\begin{tabular}{|c|c|c|c|c|c|c|c|c|c|}
\hline \multirow{2}{*}{\multicolumn{2}{|c|}{ Perlakuan }} & \multicolumn{8}{|c|}{ Perubahan contoh pada berbagai kondisi } \\
\hline & & \multicolumn{2}{|c|}{$1 \mathrm{minggu}$} & \multicolumn{2}{|c|}{2 minggu } & \multicolumn{2}{|c|}{3 minggu } & \multicolumn{2}{|c|}{4 minggu } \\
\hline Suhu & Medium & Bentuk & Warna & Bentuk & Warna & Bentuk & Warna & Bentuk & Warna \\
\hline \multirow[t]{6}{*}{$-20^{\circ} \mathrm{C}$} & PGB & $\mathrm{N}$ & $\mathrm{H}$ & $\mathrm{N}$ & $\mathrm{H}$ & $\mathrm{N}$ & $\mathrm{H}$ & $\mathrm{N}$ & $\mathrm{H}$ \\
\hline & $\mathrm{NaCl}$ & $\mathrm{N}$ & $\mathrm{H}$ & $\mathrm{N}$ & $\mathrm{H}$ & $\mathrm{N}$ & $\mathrm{H}$ & $\mathrm{N}$ & $\mathrm{H}$ \\
\hline & CTAB & $\mathrm{N}$ & $\mathrm{H}$ & $\mathrm{N}$ & $\mathrm{H}$ & $\mathrm{N}$ & $\mathrm{H}$ & $\mathrm{N}$ & $\mathrm{H}$ \\
\hline & Alkohol & $\mathrm{N}$ & $\mathrm{HC}$ & $\mathrm{N}$ & $\mathrm{HC}$ & $\mathrm{N}$ & $\mathrm{HC}$ & $\mathrm{N}$ & $\mathrm{HC}$ \\
\hline & N.medium & $\mathrm{N}$ & $\mathrm{H}$ & $\mathrm{N}$ & $\mathrm{H}$ & $\mathrm{N}$ & $\mathrm{H}$ & $\mathrm{N}$ & $\mathrm{H}$ \\
\hline & FTA & $\mathrm{R}$ & $\mathrm{HC}$ & $\mathrm{R}$ & $\mathrm{HC}$ & $\mathrm{R}$ & $\mathrm{HC}$ & $\mathrm{R}$ & $\mathrm{HC}$ \\
\hline \multirow[t]{6}{*}{$4{ }^{\circ} \mathrm{C}$} & PGB & $\mathrm{N}$ & $\mathrm{H}$ & $\mathrm{N}$ & $\mathrm{H}$ & $\mathrm{N}$ & $\mathrm{H}$ & $\mathrm{N}$ & $\mathrm{H}$ \\
\hline & $\mathrm{NaCl}$ & $\mathrm{N}$ & $\mathrm{H}$ & $\mathrm{N}$ & $\mathrm{HC}$ & $\mathrm{N}$ & $\mathrm{HC}$ & $\mathrm{N}$ & $\mathrm{HC}$ \\
\hline & CTAB & $\mathrm{N}$ & $\mathrm{H}$ & $\mathrm{N}$ & $\mathrm{H}$ & $\mathrm{N}$ & $\mathrm{H}$ & $\mathrm{N}$ & $\mathrm{H}$ \\
\hline & Alkohol & $\mathrm{N}$ & $\mathrm{CM}$ & $\mathrm{N}$ & $\mathrm{CM}$ & $\mathrm{N}$ & $\mathrm{CM}$ & $\mathrm{N}$ & $\mathrm{CM}$ \\
\hline & N.medium & $\mathrm{N}$ & $\mathrm{H}$ & $\mathrm{N}$ & $\mathrm{HC}$ & $\mathrm{N}$ & $\mathrm{HC}$ & $\mathrm{N}$ & $\mathrm{CT}$ \\
\hline & FTA & $\mathrm{R}$ & $\mathrm{HC}$ & $\mathrm{R}$ & $\mathrm{HC}$ & $\mathrm{R}$ & $\mathrm{HC}$ & $\mathrm{R}$ & $\mathrm{HC}$ \\
\hline \multirow[t]{6}{*}{$25^{\circ} \mathrm{C}$} & PGB & $\mathrm{R}$ & $\mathrm{CM}$ & $\mathrm{R}$ & $\mathrm{CM}$ & $\mathrm{R}$ & $\mathrm{CM}$ & $\mathrm{R}$ & $\mathrm{CM}$ \\
\hline & $\mathrm{NaCl}$ & $\mathrm{N}$ & $\mathrm{HC}$ & $\mathrm{N}$ & $\mathrm{C}$ & $\mathrm{N}$ & $\mathrm{C}$ & $\mathrm{N}$ & $\mathrm{C}$ \\
\hline & CTAB & $\mathrm{N}$ & $\mathrm{H}$ & $\mathrm{N}$ & $\mathrm{H}$ & $\mathrm{N}$ & $\mathrm{H}$ & $\mathrm{N}$ & $\mathrm{H}$ \\
\hline & Alkohol & $\mathrm{N}$ & $\mathrm{CM}$ & $\mathrm{N}$ & $\mathrm{CM}$ & $\mathrm{N}$ & $\mathrm{CM}$ & $\mathrm{N}$ & $\mathrm{CM}$ \\
\hline & N.medium & $\mathrm{N}$ & $\mathrm{CM}$ & $\mathrm{N}$ & $\mathrm{CT}$ & $\mathrm{N}$ & $\mathrm{CT}$ & $\mathrm{N}$ & $\mathrm{CT}$ \\
\hline & FTA & $\mathrm{R}$ & $\mathrm{HC}$ & $\mathrm{R}$ & $\mathrm{HC}$ & $\mathrm{R}$ & $\mathrm{HC}$ & $\mathrm{R}$ & $\mathrm{HC}$ \\
\hline
\end{tabular}

N, normal; R, rusak; H, hijau; HC, hijau kecokelatan; CM, Cokelat muda; C, Cokelat ; CT, Cokelat tua.

dari berbagai kondisi preservasi contoh. Nilai kemurnian DNA yang diperoleh berkisar antara 0.5 dan 2.4 (Tabel 2).

\section{Pendeteksian Fitoplasma dari Preservasi Jaringan}

Amplifikasi DNA dengan teknik PCR standar menggunakan sepasang primer $\mathrm{P} 1 / \mathrm{P} 7$ menunjukkan amplikon yang positif fitoplasma bervariasi pada masing-masing contoh tanaman (Tabel 3). Contoh tanaman yang dipreservasi dalam bufer PGB dan CTAB konsisten menghasilkan amplikon DNA positif fitoplasma pada suhu $4{ }^{\circ} \mathrm{C}$ selama 3 minggu dan suhu $-20^{\circ} \mathrm{C}$ hingga minggu ke-4. Pada suhu $25{ }^{\circ} \mathrm{C}$, DNA positif fitoplasma teramplifikasi dari contoh yang dipreservasi hanya terdapat pada medium CTAB selama 4 minggu.

Amplifikasi DNA dengan teknik nestedPCR menggunakan sepasang primer fU5/rU3 mengamplifikasi fragmen DNA fitoplasma berukuran $\pm 890 \mathrm{pb}$. Semua DNA fitoplasma yang awalnya terdeteksi negatif dari contoh tanaman yang dipreservasi pada berbagai kondisi berbeda-beda selama minggu 1 dan 4 menunjukkan semuanya berhasil teramplifikasi dengan teknik nested-PCR tersebut (Gambar 2).

\section{PEMBAHASAN}

Infeksi fitoplasma pada tanaman dapat menyebabkan gangguan keseimbangan hormon seperti peningkatan sepuluh kali lipat indole-3acetic acid (IAA). Selanjutnya fitoplasma mepengaruhi fungsi jaringan floem dalam mengangkut hasil fotosintesis. Hasil fotosintesis menumpuk pada kloroplas dan terjadi peningkatan konsentrasi gula pada daun sehingga menyebabkan gangguan fisiologi pada tanaman yang ditandai dengan gejala-gejala khas. Gejala khas pada tanaman yang terinfeksi fitoplasma meliputi proliferasi tunas kecil pada ketiak cabang, phyllody (pembentukan daun dari struktur bunga), kerdil, dan pemanjangan ruas batang yang abnormal (Bertaccini et al. 2014).

Preservasi jaringan tanaman kacang tanah bergejala penyakit sapu pada berbagai kondisi 
Tabel 2 Konsentrasi (ng $\mu \mathrm{L}^{-1}$ ) dan kemurnian DNA total dari berbagai kondisi preservasi contoh

\begin{tabular}{|c|c|c|c|c|c|c|c|c|c|}
\hline \multicolumn{2}{|c|}{ Perlakuan } & \multicolumn{4}{|c|}{ Konsentrasi DNA total } & \multicolumn{4}{|c|}{ Kemurnian DNA* } \\
\hline Suhu & Medium & 1 & 2 & 3 & 4 & 1 & 2 & 3 & 4 \\
\hline \multirow[t]{6}{*}{$-20^{\circ} \mathrm{C}$} & PGB & 81.0 & 36.0 & 120.0 & 147.0 & 2.1 & 2.1 & 1.7 & 1.7 \\
\hline & $\mathrm{NaCl}$ & 57.0 & 44.0 & 127.0 & 162.0 & 2.1 & 2.0 & 1.8 & 1.8 \\
\hline & CTAB & 40.0 & 73.0 & 171.0 & 108.0 & 2.1 & 2.1 & 1.8 & 1.6 \\
\hline & Alkohol & 65.0 & 56.0 & 198.0 & 185.0 & 2.1 & 2.1 & 1.7 & 1.8 \\
\hline & Nonmedium & 130.0 & 83.0 & 147.0 & 196.0 & 2.1 & 2.0 & 1.8 & 1.8 \\
\hline & FTA & 786.0 & 1143.0 & 1303.0 & 1033.0 & 1.0 & 0.7 & 0.8 & 0.8 \\
\hline \multirow[t]{6}{*}{$4^{\circ} \mathrm{C}$} & PGB & 10.0 & 31.0 & 67.0 & 101.0 & 2.1 & 2.0 & 2.0 & 1.9 \\
\hline & $\mathrm{NaCl}$ & 34.0 & 23.0 & 122.0 & 121.0 & 2.1 & 1.9 & 1.6 & 1.6 \\
\hline & CTAB & 47.0 & 61.0 & 201.0 & 235.0 & 2.1 & 2.1 & 1.9 & 1.9 \\
\hline & Alkohol & 45.0 & 23.0 & 146.0 & 123.0 & 2.1 & 2.0 & 1.8 & 1.7 \\
\hline & Nonmedium & 53.0 & 76.0 & 223.0 & 195.0 & 2.1 & 2.1 & 1.8 & 1.8 \\
\hline & FTA & 383.0 & 776.0 & 756.0 & 1105.0 & 0.7 & 0.6 & 0.5 & 0.7 \\
\hline \multirow[t]{6}{*}{$25^{\circ} \mathrm{C}$} & PGB & 48.0 & 33.0 & 147.0 & 146.0 & 2.1 & 2.1 & 1.7 & 1.7 \\
\hline & $\mathrm{NaCl}$ & 8.8 & 7.0 & 3.9 & 102.0 & 2.0 & 2.1 & 2.4 & 1.6 \\
\hline & СТАВ & 43.0 & 111.0 & 3.0 & 16.0 & 2.1 & 2.1 & 2.3 & 2.1 \\
\hline & Alkohol & 47.0 & 22.0 & 30. & 130.0 & 2.0 & 2.1 & 2.0 & 1.7 \\
\hline & Nonmedium & 4.7 & 82.0 & 218.0 & 202.0 & 2.2 & 1.8 & 1.8 & 1.8 \\
\hline & FTA & 780.0 & 615.0 & 1270.0 & 1285.0 & 0.7 & 0.6 & 0.6 & 0.6 \\
\hline
\end{tabular}

$1,2,3$, dan 4 ialah minggu penyimpanan

$*<1.8$, kontaminasi protein; $1.8-2.0$, DNA Murni; $>2.0$, kontaminasi RNA

Tabel 3 Hasil PCR standar dengan primer P1/P7 menggunakan DNA fitoplasma dari berbagai kondisi preservasi contoh pada beberapa waktu penyimpanan

\begin{tabular}{|c|c|c|c|c|c|c|c|c|c|c|c|c|c|}
\hline \multicolumn{2}{|c|}{ Perlakuan } & \multicolumn{3}{|c|}{1 Minggu } & \multicolumn{3}{|c|}{2 Minggu } & \multicolumn{3}{|c|}{3 Minggu } & \multicolumn{3}{|c|}{4 Minggu } \\
\hline Suhu & Medium & 1 & 2 & 3 & 1 & 2 & 3 & 1 & 2 & 3 & 1 & 2 & 3 \\
\hline \multirow[t]{6}{*}{$-20^{\circ} \mathrm{C}$} & PGB & + & + & ++ & ++ & + & + & + & - & \pm & - & - & + \\
\hline & $\mathrm{NaCl}$ & - & - & - & - & - & - & - & - & - & - & - & - \\
\hline & CTAB & + & + & ++ & ++ & + & - & ++ & + & - & - & - & + \\
\hline & Alkohol & + & - & - & ++ & + & - & - & - & - & - & - & - \\
\hline & Nonmedium & - & - & - & - & - & - & - & - & - & - & - & - \\
\hline & FTA & - & - & - & - & - & - & - & - & - & - & - & - \\
\hline \multirow[t]{6}{*}{$4^{\circ} \mathrm{C}$} & PGB & ++ & \pm & ++ & ++ & \pm & ++ & - & - & + & - & - & - \\
\hline & $\mathrm{NaCl}$ & - & - & - & - & - & - & - & - & - & - & - & - \\
\hline & CTAB & + & + & ++ & ++ & + & ++ & + & - & + & - & - & - \\
\hline & Alkohol & \pm & \pm & - & ++ & + & - & - & - & - & - & - & - \\
\hline & Nonmedium & ++ & ++ & ++ & ++ & \pm & - & - & - & - & - & - & - \\
\hline & FTA & - & - & - & - & - & - & - & - & - & - & - & - \\
\hline \multirow[t]{6}{*}{$25^{\circ} \mathrm{C}$} & PGB & ++ & \pm & - & - & - & - & - & - & - & - & - & - \\
\hline & $\mathrm{NaCl}$ & - & - & \pm & - & - & - & - & - & - & - & - & - \\
\hline & CTAB & + & - & + & \pm & \pm & - & - & - & + & \pm & - & - \\
\hline & Alkohol & - & - & - & - & + & - & - & - & - & - & - & - \\
\hline & Nonmedium & + & \pm & - & - & - & - & - & - & - & - & - & - \\
\hline & FTA & - & - & - & - & - & - & - & - & - & - & - & - \\
\hline
\end{tabular}

-, pita DNA fitoplasma negatif; \pm , pita DNA samar (sangat tipis); +, pita DNA fitoplasma positif; ++, pita DNA fitoplasma positif dan tebal.

1, 2, dan 3 ialah ulangan perlakuan. 

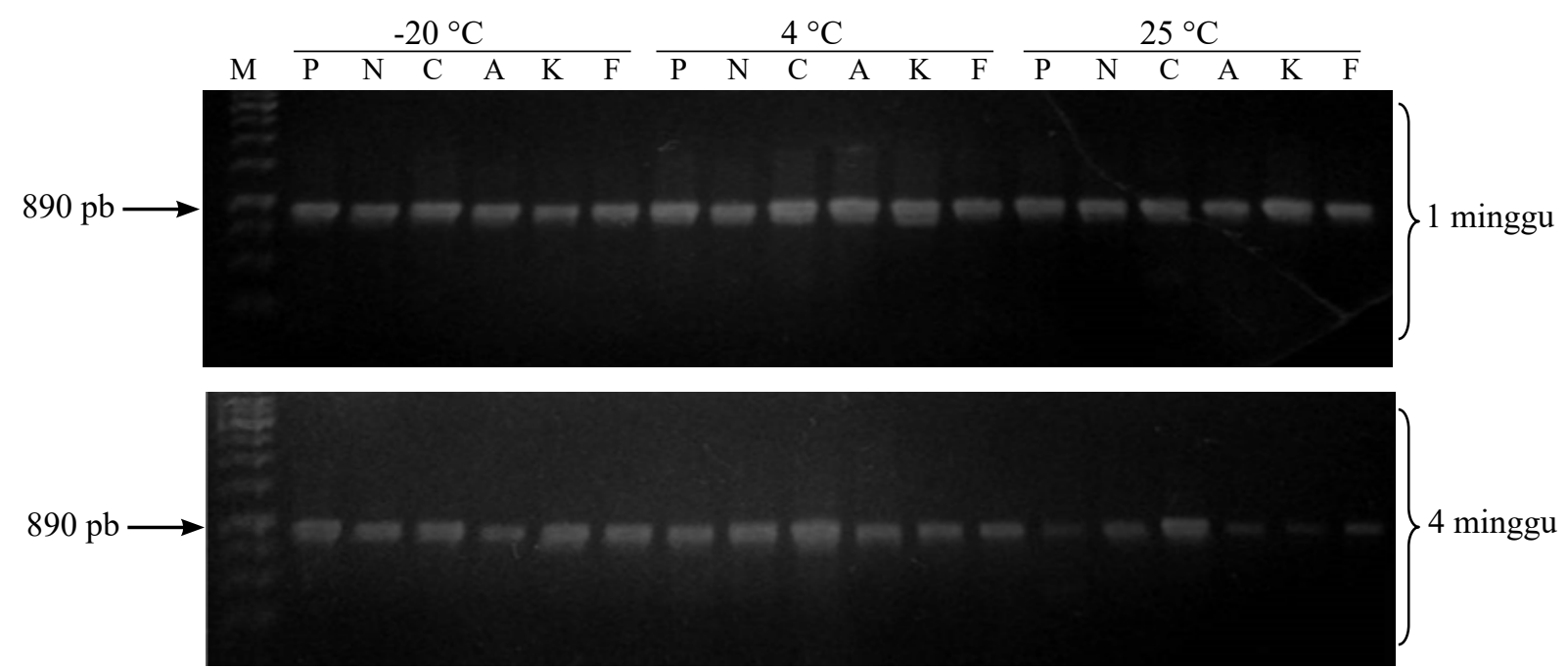

Gambar 2 Visualisasi fragmen DNA fitoplasma hasil nested-PCR menggunakan primer P1/P7 dilanjutkan dengan primer fU5/rU3 dari penyimpanan tanaman kacang tanah bergejala sapu. M, Penanda DNA 1 Kb; P, PGB; N, NaCl; C, CTAB; A, Alkohol; K, Non Media; F, FTA.

waktu dipengaruhi oleh suhu dan medium. Namun tidak semua kombinasi suhu dan medium mampu mempertahankan keawetan jaringan tanaman. Hanya beberapa medium tertentu seperti medium PGB pada suhu rendah dan medium CTAB pada suhu yang tinggi dapat menjaga keawetan jaringan tanaman. Suhu diduga merupakan faktor utama yang dapat memengaruhi perubahan jaringan tanaman. Hal ini dibuktikan dengan semakin tinggi suhu maka semakin cepat proses kerusakan jaringan tanaman yang disimpan. Begitupun sebaliknya, semakin rendah suhu maka semakin lama proses terjadinya kerusakan sehingga contoh masih terlihat segar selama waktu tertentu. Suhu yang sangat rendah dapat secara efektif menghentikan pertumbuhan dan perkembangan biologi dalam sel sehingga keutuhan sel-sel terjaga dalam jangka panjang (Zeliang dan Pattanayak 2012). Suhu yang rendah menimbulkan sel-sel dalam jaringan membeku sehingga proses metabolisme semua sel hidup terhenti. Jaringan daun terinfeksi fitoplasma yang disimpan selama 32 hari pada suhu $-20{ }^{\circ} \mathrm{C}$ masih dalam keadaan segar. Adapun penyimpanan contoh pada suhu $4{ }^{\circ} \mathrm{C}$ dalam waktu lama dapat mengakibatkan perubahan jaringan tanaman dan meningkatkan infeksi berbagai patogen sehingga sulit digunakan untuk deteksi DNA fitoplasma (Wongwarat et al. 2011).
Medium penyimpanan bufer PGB pada suhu rendah $\left(-20{ }^{\circ} \mathrm{C}\right.$ dan $\left.4{ }^{\circ} \mathrm{C}\right)$ dan bufer CTAB pada suhu standar $\left(25{ }^{\circ} \mathrm{C}\right)$ cukup efektif mempertahankan keawetan contoh selama proses penyimpanan. Bufer PGB yang mengandung senyawa polyvinylpyrrolidone (PVP), asam askorbat (AA), dan bovine serum albumin (BSA) serta sukrosa diduga dapat mencegah munculnya senyawasenyawa kontaminan perusak sel dalam jaringan tanaman dan menstabilkan DNA. Adapun bufer CTAB mengandung senyawasenyawa yang dapat mencegah munculnya senyawa kontaminan perusak DNA. Menurut Hodkinson et al (2007) penyimpanan contoh menggunakan bufer CTAB dapat mencegah terjadinya antioksidan dengan merusak enzim yang menghasilkan senyawa kontaminan dalam jaringan sehingga kehomogenan jaringan tanaman terjaga dan tidak mengalami kerusakan.

Perbedaan konsentrasi DNA dipengaruhi adanya sisa larutan-larutan hasil penyimpanan contoh yang ikut terbawa DNA dalam proses ekstraksi. Kemurnian yang sesuai nisbah menandakan bahwa hasil DNA cukup murni dengan kontaminan protein maupun RNAyang minimum. Nilai kemurnian DNA $>2.0$ diduga terkontaminasi RNA yang tidak terpecah dalam proses ekstraksi sehingga mengganggu tingkat kemurnian DNA. DNA yang murni 
dengan jumlah yang relatif cukup banyak dapat digunakan untuk proses amplifikasi DNA hingga beberapa kali.

Contoh yang dipreservasi dalam bufer PGB pada suhu rendah $\left(-20{ }^{\circ} \mathrm{C}\right.$ dan $\left.4{ }^{\circ} \mathrm{C}\right)$ dan bufer CTAB pada suhu standar $\left(25^{\circ} \mathrm{C}\right)$ lebih baik untuk menjaga keutuhan DNA fitoplasma dalam jaringan tanaman. PGB mengandung senyawa PVP yang dapat mengurangi kandungan fenol pada jaringan tanaman. Bufer CTAB yang mengandung senyawa PVP, mercaptoethanol, dan $\mathrm{NaCl}$ yang dapat menghambat senyawa kontaminan seperti fenolik, enzim DNAse, dan polisakarida. Oleh karena itu, ketika proses preservasi dan ekstraksi, DNA fitoplasma terlindungi oleh senyawa-senyawa dalam bufer PGB dan CTAB hingga proses amplifikasi menghasilkan pita DNA positif dan tebal pada gel agarosa.

Adanya pita DNA fitoplasma yang tidak terlihat bukan berarti selalu negatif, tetapi dapat diduga karena konsentrasi DNA rendah ataupun konsentrasi yang terlalu tinggi dan adanya inhibitor yang terbawa bersama DNA templat sehingga mengganggu reaksi amplifikasi dengan PCR standar. Inhibitor berupa polisakarida, polifenol maupun konsentrasi garam yang tinggi pada proses amplifikasi PCR mampu menghambat laju aktivitas Taq polymerase dalam mensintesis DNA (Mullis dan Faloona 1987).

Penelitian ini menunjukkan bahwa preservasi contoh hingga minggu ke-4 jaringan tanaman kacang tanah bergejala penyakit sapu pada berbagai suhu dan medium tetap efektif untuk mendeteksi fitoplasma melalui pengujian nested-PCR. Pengujian nested-PCR dirancang untuk meningkatkan sensitivitas dan kespesifikan, khususnya amplifikasi fitoplasma dari contoh dengan konsentrasi DNA yang rendah sehingga dapat mengganggu keberhasilan PCR. Selain itu, amplikon DNA hasil PCR pertama yang telah terencerkan dan selanjutnya menjadi templat pada PCR kedua (nested-PCR) mampu mengurangi konsentrasi inhibitor pada reaksi PCR kedua sehingga hasil amplifikasi DNA fitoplasma lebih optimal (Prasetyo 2012).

\section{DAFTAR PUSTAKA}

Bertaccini A, Duduk B, Paltrinieri S, Contaldo N. 2014. Phytoplasmas and phytoplasma diseases: a severe threat to agriculture. Amer J Sci Res. 5:1763-1788. DOI: https://doi.org/10.4236/ajps.2014.512191.

Dellaporta SL, Wood J, Hicks JB.1983. A plant DNA minipreparation: version II. Plant Mol Biol Rep. 1:19-21. DOI: https:// doi.org/10.1007/BF02712670.

Duduk B, Paltrinieri S, Lee IM, Bertaccini A. 2013. Nested PCR and RFLP Analysis Based on the 16S rRNA Gene. Di dalam Dickinson M, Hodgetts J, editor. Phytoplasma methods and protocols. New York (US): Humana Press. hlm 159-171.

Gundersen DE, Lee IM. 1996. Ultrasensitive detection of phytoplasmas by nested-PCR assays using two universal primer pairs. Phytopathol Mediterr. 35:144-151.

Hodkinson TR, Waldren S, Parnell JAN, Kelleher CT, Salamin K, Salamin N. 2007. DNA banking for plant breeding, biotechnology and biodiversity evaluation. J Plant Res. 120:17-29. DOI: https://doi. org/10.1007/s10265-006-0059-7.

Lorenz KH, Schneider B, Ahrens U, Seemuller E. 1995. Detection of the apple proliferation and pear decline phytoplasmas by PCR amplification of ribosomal and non-ribosomal DNA. Phytopathology. 85:771-776. DOI: https://doi.org/10.1094/ Phyto-85-771.

Mullis KB, Fallona FA. 1987. Specific synthesis of DNA in vitro via a polymerasecatalyzed chain reaction. Didalam: Methods in Enzymology 155. Academic Press, Inc. hlm 335-350.

Mutaqin KH, Suseno R, Tjahjono B, Hidayat P. 2003. Deteksi molekuler dan uji penularan fitoplasma asal rumput bermuda. Hayati. 10(2):66-70.

Nejat N, Vadamalai G. 2013. Diagnostic techniques for detection of phytoplasma diseases: past and present. J Plant Dis Prot. 120(1):16-25. DOI: https://doi. org/10.1007/BF03356449. 
Nugroho S, Suseno R, Hidayat SH, Hidayat P. 2000. Evaluasi ketahanan beberapa varietas kacang tanah terhadap fitoplasma. Bul HPT. 12(2):48-52.

Prasetyo AE. 2012. Deteksi dan identifikasi fitoplasma yang berasosiasi dengan penyakit layu kelapa di Pulau Derawan Kalimantan Timur [tesis]. Bogor (ID): Institut Pertanian Bogor.

Wongwarat T, Sakuanrungsirikul S, Theerakulpisut P. 2011. Effective methods of preserving SCWL-diseased sugarcane leaves for genomic DNA extraction and molecular detection of phytoplasma.
Afr J Biotech. 10(53):10871-10876. DOI: https://doi.org/10.5897/AJB11.1570.

Zeliang PK, Pattanayak A. 2012. Fundamental crybiology and basic physical, thermodynamical and chemical aspects of plant tissue cryopreservation. Di dalam Abdurakhmonov I, editor. Biochemistry, Genetics and Molecular Biology: Plant Breeding. https://www.intechopen.com/ books/plant-breeding/fundamentalcryobiology-and-basic-physicalthermodynamical-and-chemical-aspectsof-plant-tissue-cryoInTech. 